\title{
Endocannabinoid System: the Direct and Indirect Involvement in the Memory and Learning Processes-a Short Review
}

\author{
Marta Kruk-Slomka $^{1} \cdot$ Agnieszka Dzik $^{1} \cdot$ Barbara Budzynska $^{1} \cdot$ Grazyna Biala $^{1}$
}

Received: 30 September 2016 / Accepted: 21 November 2016/Published online: 6 December 2016

(C) The Author(s) 2016. This article is published with open access at Springerlink.com

\begin{abstract}
The endocannabinoid system via cannabinoid (CB: CB1 and CB2) receptors and their endogenous ligands is directly and indirectly involved in many physiological functions, especially in memory and learning processes. Extensive studies reported that this system strictly modulates cognitionrelated processes evaluated in various animal models. However, the effects of cannabinoids on the cognition have been contradictory. The cannabinoid compounds were able to both impair or improve different phases of memory processes through direct (receptor related) or indirect (non-receptor related) mechanism. The memory-related effects induced by the cannabinoids can be depended on the kind of cannabinoid compound used, dosage, and route of administration as well as on the memory task chosen. Therefore, the objectives of this paper are to review and summarize the results describing the role of endocannabinoid system in cognition, including various stages of memory.
\end{abstract}

Keywords Endocannabinoid system · Cannabinoid receptors $\cdot$ Memory and learning $\cdot$ Cognition $\cdot$ Animal models of memory

\section{Abbreviations \\ 2-AG 2-Arachidonoylglycerol \\ $\Delta$-9-THC $\quad \Delta$-9-Tetrahydrokannabinol \\ AEA Anandamide}

Marta Kruk-Slomka

marta.kruk@umlub.pl

1 Department of Pharmacology and Pharmacodynamics, Medical University of Lublin, Chodzki 4a Street, 20-093 Lublin, Poland

$\begin{array}{ll}\mathrm{Ca}^{2+} & \text { Calcium ions } \\ \text { CB } & \text { Cannabinoid } \\ \text { CB1KOS } & \text { CB1 receptor genetic knockout mice } \\ \text { CB2KOS } & \text { CB2 receptor genetic knockout mice } \\ \text { CFC } & \text { Contextual fear conditioning } \\ \text { CNS } & \text { Central nervous system } \\ \text { ECS } & \text { Endocannabinoid system } \\ \text { ETM } & \text { Elevated T-maze } \\ \text { FAAH } & \text { Fatty acid amid hydrolase } \\ \text { GABA } & \text { Gamma-aminobutyric acid } \\ \text { IA } & \text { Inhibitory avoidance } \\ \text { Intra-BLA } & \text { Intra-basolateral amygdala } \\ \text { Intra-PLC } & \text { Intra-prelimbic } \\ \text { i.p. } & \text { Intra-peritoneally } \\ \text { MAGL } & \text { Monoacylglycerol lipase } \\ \text { NADA } & N \text {-arachidonoyl dopamine } \\ \text { NAGly } & N \text {-arachidonylglycine } \\ \text { OEA } & \text { Oleoylethanolamine } \\ \text { OF } & \text { Open field } \\ \text { ORT } & \text { Object recognition task } \\ \text { PA } & \text { Passive avoidance } \\ \text { PCR } & \text { Polymerase chain reaction } \\ \text { PEA } & \text { Palmitoylethanolamide } \\ \text { RAM } & \text { Radial arm maze } \\ \text { VTA } & \text { Ventral tegmental area } \\ \text { WMT } & \text { Water maze test } \\ & \end{array}$

\section{Pharmacology of the Endocannabinoid System}

The endocannabinoid system (ECS) is a lipid signaling system, which is functionally active since the early stages of brain development and remains active during both prenatal and post-natal life [1-3]. This system consists of the cannabinoid (CB) receptors, their endogenous ligands, the enzymes 
for the synthesis and degradation of endocannabinoids, and the reuptake transport system [4].

The discovery of specific $\mathrm{CB}$ receptors, followed by identification of their endogenous ligands, gave an opportunity to the extensive research on the significance of this system for the proper functioning of the organism. CB receptors were discovered in late 1980s and then were divided into two different subtypes of $\mathrm{G}$ protein-coupled receptors [5]. Currently, two types of $\mathrm{CB}$ receptors are known. The pharmacological effects are mainly exerted through the activation of Gi/o protein-coupled membrane receptors $\mathrm{CB} 1$ and CB2. Despite the fact that both $\mathrm{CB} 1$ and $\mathrm{CB} 2$ receptors belong to the group of $\mathrm{G}$ protein-coupled receptors and are characterized by significant homology, they differ in their function and specificity of cellular expression [6].

CB1 receptors are located mainly in the central nervous system (CNS), and they are one of the most abundantly expressed neuronal receptors in the CNS, which suggests their important role in the function of the CNS. These receptors are widely expressed in multiple brain areas with the highest concentration in the regions associated with cognition and movement like amygdala, hippocampus, septum, brain cortex, globus pallidus, substantia nigra, cerebellum, and lateral caudate putamen [4]. Additionally, they are also present at lower concentration in a variety of peripheral tissues, both on sensory nerve fibers and in the autonomic nervous system [6-8]. CB1 receptors are localized presynaptically on glutamatergic and gamma-aminobutyric (GABA) acid axon terminals [9]. In the hippocampus, $\mathrm{CB} 1$ receptors are located mainly in GABA-ergic, inhibitory interneurons. They are also present in the hippocampal glutamatergic axon terminals, but their concentration is at least 20 times lower than in the presynaptic areas of this brain structure. Activation of CB1 receptors is connected with inhibition of adenyl cyclase as well as calcium channels and leads to activation of potassium channels; thus, it contributes to short-term depression of neurotransmitter release in corticostriatal GABA-ergic and glutamatergic neurons [5]. CB1 receptors are also present on noradrenergic terminals, and their blockade increases release of norepinephrine in limbic regions $[10,11]$. Owing to their localization, CB1 receptors control both cognitive process and emotional behavior, including stress, fear, or anxiety [12-17] by modulating neuronal signaling and synaptic plasticity [18].

In turn, CB2 receptors are present mainly peripherally and are the most abundant in the immune system in a variety of immune cells including B lymphocytes, natural killer cells, monocytes, macrophages, polymorphonuclear neutrophils, and $\mathrm{T}$ cells $[4,6]$. Thus, they are mainly involved in immune system functions $[6,19]$. However, the CB2 receptors have also been found in microglial cells in the CNS. The gathered data suggests that $\mathrm{CB} 2$ receptors modulate neuronal function and play a role in psychiatric disorders. Polymorphism of CB2 receptor gene encoding $\mathrm{CB} 2$ receptors in humans is related to schizophrenia [20, 21], depression [22], and bipolar disorders [23]. Moreover, in CB2-knockout mice, schizophrenia-like symptoms were observed [24]. Additionally, the CB2 receptors modulate both excitatory $[25,26]$ and inhibitory synaptic transmissions in the hippocampus [27-29]. It has been reported that the activation of $\mathrm{CB} 2$ receptors reduces pain [30], impulsive behavior [31], locomotor activity of rodents [22, 32, 33], and vomiting of ferrets [34]. Stimulation of CB2 receptors also decreases the excitability of peripheral sensory neurons [30], cortical pyramidal neurons [35], and dopaminergic neurons in the ventral tegmental area (VTA) [36] (Fig. 1).

As mentioned earlier, endocannabinoids are synthesized on demand from lipid precursors derived from the enzymatic cleavage of cell membrane constituents in response to neuronal membrane depolarization or immune cell activation and are released from post-synaptic membranes as retrograde messengers onto presynaptic terminals of excitatory or inhibitory character, thus suppressing both inhibitory and excitatory signaling within specific neuronal area. Endocannabinoids control synaptic plasticity by an influence on neurotransmitter release [5, $6,18]$. They have affinity for both $\mathrm{CB} 1$ and $\mathrm{CB} 2$ receptors [6]. Henceforth, two endogenous cannabinoids (endocannabinoids) were discovered: arachidonoylethanolamide (anandamide (AEA)) and 2-arachidonoylglycerol (2-AG) [5]. They remain the two most studied endogenous substances from the others known so far, including virodhamine, noladin ether, palmitoylethanolamide (PEA), $N$-arachidonoyl dopamine (NADA), $N$-arachidonylglycine (NAGly), oleamide, and oleoylethanolamine (OEA) [37] (Table 1).

2-AG is mainly produced in the CNS, and AEA is produced at low levels in the periphery and the CNS [38]. Production of endogenous cannabinoids is increased in response to pathogenic stimulus. Particularly important to immune modulation is a fact that the production of endocannabinoids is stimulated by activation of immune cells (macrophages) and dendritic cells, and stimulated immune cells have reduced the expression of endocannabinoid-degrading enzymes [39]. Endocannabinoids are metabolized by degradative enzymes like fatty acid amid hydrolase (FAAH), which metabolizes AEA as well as 2-AG, and monoacylglycerol lipase (MAGL), which metabolizes 2-AG [8].

It should be also noted that there are two novel G proteincoupled orphan receptors GPR55 and GPR119, which have been recently defined as CB receptors [40]. Though showing virtually no apparent homology to either of the classical $\mathrm{CB}$ receptors, GPR55 was identified as a novel CB receptor [41]. The CB-sensitive receptor GPR55 was identified and cloned by Sawzdargo et al. [42]. Its presence in the brain, including the hippocampus, has been proved by using quantitative polymerase chain reaction (PCR) $[43,44]$. GPR55 activity can be modulated by phytocannabinoids and endocannabinoids [38, 44]. The endocannabinoids that have affinity for GPR55 receptors probably include AEA, 2-AG, PEA, and others [45]. Moreover, 
Fig. 1 The distribution of CB receptors in the CNS and periphery

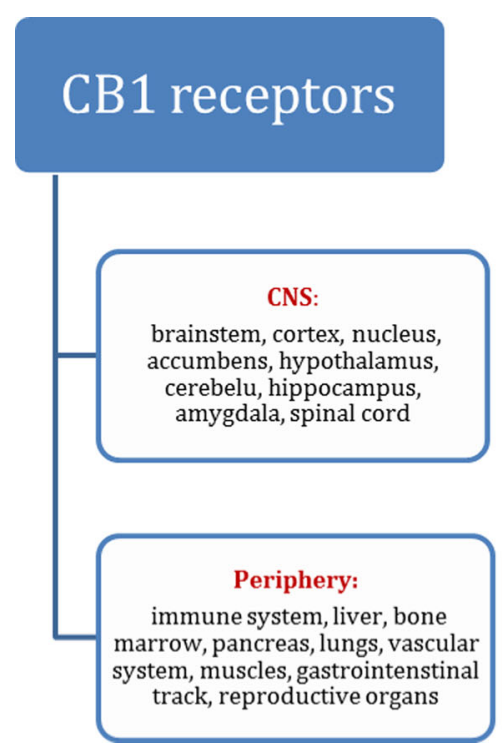

\section{CB2 receptors}

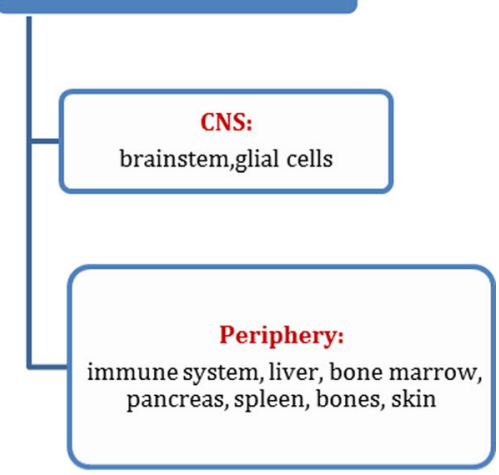

Table 1 The chemical structure of endocannabinoids

\begin{tabular}{ll}
\hline Anandamide & $5 \mathrm{Z}, 8 \mathrm{Z}, 11 \mathrm{Z}, 14 \mathrm{Z}) \mathrm{N}-(2-$ \\
hydroxyethyl)icosa-5,8,11,14- \\
tetraenamide
\end{tabular}


Table 1 (continued)

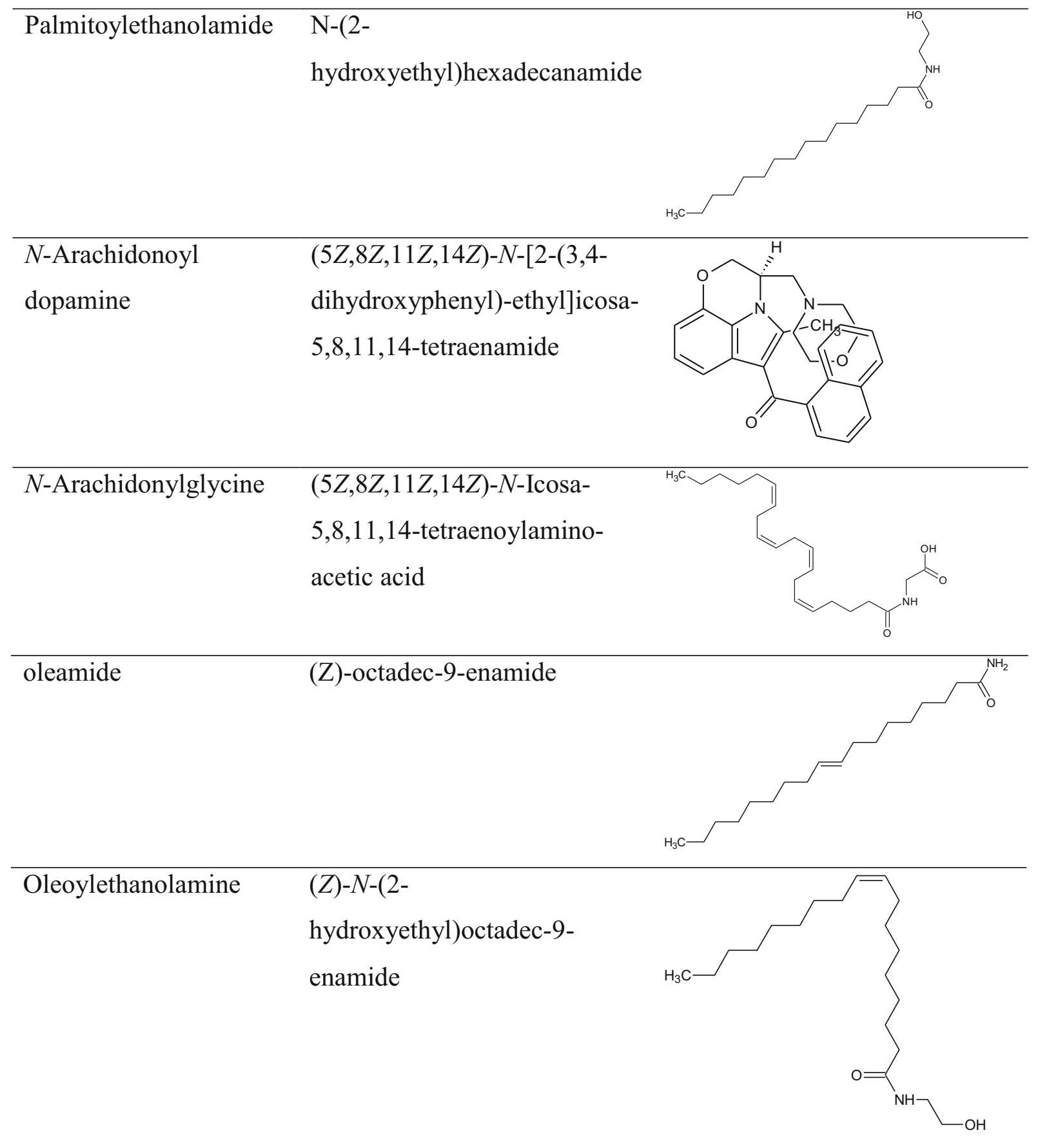

recent studies suggest that L- $\alpha$-lysophosphatidylinositol, which activates GPR55 but not CB1 or CB2 receptors, could also be its endogenous ligand [46, 47]. Contrariwise, cannabidiol (CBD), a major constituent of Cannabis sativa, is a GPR55 antagonist, with low affinity for CB1 receptors [44, 48]. In turn, GPR119 receptors are expressed on enteroendocrine L cells of the gastrointestinal tract. They regulate the release of the antidiabetic peptide glucagon-like peptide-1 [49-51]. These receptors are also found on pancreatic $\beta$ cells in the islets of
Langerhans. OEA is one of the most potent ligands for these receptors, but they are not activated by AEA and only weakly by PEA [41]. However, the pharmacology of both GPR55 and GPR119 is enigmatic, and its adaptive role in the brain remains unknown. Therefore, the explanation of their exact role in the ECS requires further studies.

As we described previously, the ECS, through CB receptors, and its interactions with a multitude of neurotransmitters and receptors are directly and indirectly involved in many 
physiological and physical functions [52-61]. In the recent years, a large number of studies focused on learning and memory processes. The substances exerting their action through ECS are able to both impair and enhance different phases of memory formation through direct and indirect mechanisms. However, the results of multiple studies show that manipulations performed on the ECS in reference to learning and memory bring contradictory results. Thus, the purpose of this paper is to review and summarize findings connected with the involvement of the ECS in the different memory stages.

\section{The Role of CB Receptor in the Memory-Related Responses in Animal Models of Memory: CB Receptor Agents}

\section{CB1 Receptor Ligands}

The influence of the CB1 receptor ligands on memory and learning processes has been widely documented by various experiments and clinical studies [8,62-66]. Nevertheless, the results are still contradictory. In this part of the present elaboration, we will summarize the effects of the $\mathrm{CB} 1$ receptor ligands, including $\mathrm{CB} 1$ receptor agonist and $\mathrm{CB} 1$ antagonists (and inverse agonists) on different memory stages.

Studies have demonstrated that an acute administration of synthetic CB1 receptor agonists: CP55940 and HU-210 attenuated acquisition of memory in various animal models, e.g., the water maze test (WMT), the object recognition task (ORT), and the contextual fear conditioning (CFC) test [67-71]. Similarly, Mazzola et al. [68] and others [71] confirmed these effects of direct activation of natural CB1 receptor agonist $-\Delta$ 9-tetrahydrokannabinol ( $\Delta$ 9-THC). $\Delta$ 9-THC $(3.0,5.0$, and $6.0 \mathrm{mg} / \mathrm{kg}$ ) injected intra-peritoneally (i.p.) $30 \mathrm{~min}$ before the learning trial significantly impaired memory acquisition using the passive avoidance (PA) task in rats. This deterioration was reversed by pretreatment with $1 \mathrm{mg} / \mathrm{kg}$ of rimonabant (SR141716A), a CB1 receptor antagonist. Moreover, indirect stimulation of CB1 receptors impaired acquisition of memory in the recognition memory test [72].

In turn, Pamplona and Takahashi investigated whether CB1/CB2 receptor agonist, WIN 55,212-2, is able to influence the acquisition of fear conditioning using tone and contextual versions [69]. They revealed that this compound (2.5 and $5.0 \mathrm{mg} / \mathrm{kg}$, i.p.), administered before conditioning and before testing, impaired memory processes in the CFC and did not affect the freezing behavior induced by tone presentation; therefore, non-state-dependent effects of WIN 55,212-2 on tested animals were observed. During the course of further studies, selective CB1 antagonists (SR141716A and SR147778) were administered, in order to establish whether impaired contextual conditioning would be prevented. Preadministration of SR141716A (1.0 mg/kg, i.p.) or
SR147778 (1.0 mg/kg, i.p.) has in fact prevented the impairment. These findings demonstrate that an acute administration of WIN 55,212-2 dose-dependently impairs the acquisition of memory in the CFC test, which is a hippocampus-dependent learning and memory task and does not affect tone fear conditioning, which is considered independent of the hippocampus [73, 74]. Likewise, chronic administration of WIN 55,212-2 significantly impaired spatial memory in rats evaluated in the WMT [75]. Additionally, Kruk-Slomka et al. [64] revealed that WIN 55,212-2 impaired both acquisition and consolidation of memory in PA test in mice. The evidence gathered from this experiment reaffirms that the effects of the $\mathrm{CB}$ receptor agonists are selective for the hippocampusdependent aversive memories in rats.

Contradictory data concerning the influence of $\mathrm{CB} 1$ on memory consolidation has also been reported. It has been demonstrated that post-training administration of $\mathrm{CB} 1$ receptor agonist HU-210 as well as a combined CB1/CB2 receptor agonist WIN 55,212-2 attenuated consolidation of memory in the CFC test, the WMT, and the ORT [7, 76-78]. Indeed, Maćkowiak et al. [77] investigated the role of CB1 receptors in hippocampal-dependent memory consolidation using HU210. The results indicated that HU-210 impaired the consolidation of fear memory in the CFC test. These detrimental effects were abolished by a CB1 receptor antagonist AM251. These findings may suggest the involvement of CB1 receptors in memory and learning processes. The results of the studies indicated also that AM251 blocked the effects of HU-210 on freezing behavior but did not affect memory consolidation in the CFC on its own. Thus, the blockade of CB1 receptors does not affect consolidation of contextual memory [79] and disrupts memory consolidation in a step-down inhibitory avoidance (IA) $[80,81]$.

Similar effects of WIN 55,212-2 on memory consolidation were observed in spatial memory formation using the WMT [78]. Yim et al. administered WIN 55,212-2 systemically and intra-cranially to assess both methods of drug delivery. They demonstrated that this $\mathrm{CB} 1 / \mathrm{CB} 2$ receptor ligand impairs the consolidation of long-term spatial memory. Similar long-term memory impairments were observed in both systemic injections and intra-hippocampal infusions of WIN 55,212-2. As CB2 receptors are not expressed in the hippocampus, therefore, the observed impairments provide an indirect support that this effect was reached by targeting CB1 receptors [78]. Nonetheless, it has been noted that intra-basolateral amygdala (intra-BLA infusion) of WIN 55,212-2 facilitated memory consolidation in rats evaluated in the IA task or had no effect in the mentioned animal model $[82,83]$. On the other hand, post-training intra-hippocampal injection of this drug impaired consolidation of memory in several behavioral tasks [84]. WIN 55,212-2 was also evaluated in the experiments conducted by Clarke et al. [76]. They examined the effects of post-training activation of hippocampal $\mathrm{CB}$ receptors on 
the consolidation of object recognition memory. The results of the study were in agreement with the evidence provided by Yim et al. [78]. WIN 55,212-2 impaired the consolidation phase of memory formation. Amnestic effect of this compound was completely reversed by coadministration of CB1 receptor antagonist, AM251, as well as mimicked by $\mathrm{CB} 1$ receptor agonist, ACEA, but not by $\mathrm{CB} 2$ receptor agonist, JWH-015 [78]. These findings are also in agreement with the results published by Moshfegh et al. [85]. They used a step-down PA task as a model of learning. The results indicated that post-training administration of WIN 55,212-2 produced an amnestic response. All the effects described previously endorsed the hypothesis that the memory impairments were due to activation of hippocampal CB1 receptors.

Systemic administration of $\mathrm{CB} 1$ receptor antagonists, e.g., rimonabant (SR141716A) or AM251, has been tested in various learning paradigms alone or coadministered with CB1 agonists [61, 63, 64, 81, 86-89].

SR141716A is a selective and potent CB1 receptor antagonist [90]. It also presents features of an inverse agonist [91]. An acute, pretraining administration of SR141716A facilitated the acquisition of memory in rodents observed in the PA test, the elevated T-maze (ETM) test, and social recognition memory task $[61,89]$ and impaired the acquisition of memory assessed in the spatial memory test [92]. Additionally, systemic, posttraining administration of rimonabant enhanced memory consolidation in the radial arm maze (RAM) [89]. Also, Robinson et al. studied the effects of SR141716A on spatial learning and memory formation using the WMT [92]. Two experiments were performed. In the first one, rimonabant was administered i.p., before or immediately after training. The results indicated that systemic administration before training induced deficits in acquisition of spatial reference memory; however, pretraining before drug treatment eliminated this effect. The experiment revealed that rimonabant-induced memory deficits appeared as a result of anxiogenic effects of the drug. Post-training injections had no effect. In the second experiment, rimonabant was administered intra-hippocampally during the training and the results indicated that this drug enhanced acquisition learning and exerted no effect on consolidation of memory. Subcutaneous injections did not affect memory in any way [92].

The results from these described experiments demonstrated that rimonabant produced various effects dependent upon the route of administration, the timing of infusion, and the dose of the drug. Similarly, Lichtman reported an improvement of memory acquisition induced by administration of SR141716A [93]. Likewise, Wolff and Leander showed the enhancement of the consolidation processes when the animals were tested in the RAM test [89]. Furthermore, Wolff and Leander [89] proved a dose of $1.0 \mathrm{mg} / \mathrm{kg}$ of SR141716A to be effective. The higher dose of $3.0 \mathrm{mg} / \mathrm{kg}$ did not improve the consolidation, what is consistent with the results obtained by Lichtman [93] in the same task. Pro-cognitive effects of rimonabant were also shown in the experiments performed by Takahashi et al. [88]. Administration of $1.0 \mathrm{mg} / \mathrm{kg}$ of rimonabant produced an improvement in memory acquisition and consolidation in the ETM task. Neither lower $(0.5 \mathrm{mg} / \mathrm{kg})$ nor higher $(2.0 \mathrm{mg} / \mathrm{kg})$ doses were able to improve acquisition. Additionally, facilitation of short-term olfactory memory in the social recognition test was described by Terranova et al. [88]. On the other hand, Marsicano and colleagues failed to prove any effect of rimonabant on the consolidation of aversive memories [94]. This result may be accounted to the different mouse strain. The single dose used by Marsicano et al. [94] was also higher than the maximum dose used in the studies described previously.

AM251 is a member of the same CB group of diarylopyrazoles as SR141716A, presenting the features of CB1 receptor antagonist and inverse agonist [4]. The posttraining administration of AM251 interfered consolidation of memory-related processes in the step-through IA task or CFC task [82, 87]. De Oliveira Alvares et al. [81] investigated the effects of intra-hippocampal administration of AM251 in two behavioral tasks: the IA and the open field (OF) habituation task. The results indicated that AM251 exerted a disruptive effect on memory consolidation in the IA test, but not in the OF habituation test. Similarly, Kruk-Slomka and Biala [63] confirmed that an acute injection of AM251 improved the short-term and long-term memory stages (acquisition, consolidation, and/or retrieval) in the IA task. The effect seemed to be purely mnemonic since the drug showed no motor performance effects, which could favor a false positive for the intermediate dose in the IA test session. It needs to be highlighted that the amnestic effect took place with the lower, more selective dose, not with the higher one (that one could bind to the non-specific targets in the hippocampus). The different responses observed in two behavioral tasks require explanation. The findings of the study suggest that hippocampal endocannabinoids are not acting upon the consolidation of the OF habituation task. The fact that the $\mathrm{OF}$ was not recruited and the IA was sensitive to AM251 raises the possibility that this system requires some degree of aversiveness or alertness to be recruited. The impairing effect of AM251 on memory consolidation was also confirmed by Bucherelli et al. in 2006 [87]. De Oliveira Alvares and colleagues replicated the previous findings [80]. Afterwards, Bialuk and Winnicka [4] performed a study in an attempt to determine the influence of different doses of AM251 on recognition memory. In order to evaluate the effects of AM251 on acquisition of information, the drug was given 15 min before learning trial, and to establish its influence on consolidation of information, it was injected immediately after the trial in the ORT. The results of the study indicated that AM251 significantly improved both acquisition and consolidation of information; however, these effects were observed only when dose of $1 \mathrm{mg} / \mathrm{kg}$ was administered. Higher doses did not exert any influence on it. The 
memory-improving effect is in an agreement with the results obtained in experiments with SR141716A [4].

Interesting experiments in the context of our paper seem to be the studies of Tan et al. [95]. The authors used CB antagonist, agonist, and reuptake inhibitor, AM251, WIN 55,212-2, and AM404, respectively. The substances were administered bilaterally as an intra-BLA and intra-prelimbic (intra-PLC) microinfusion in rats. The results indicated that pharmacological inhibition of intra-BLA CB1 receptor transmission dosedependently blocked the acquisition of olfactory fear memory, simultaneously leaving unaffected recall and consolidation of these memories in an olfactory fear conditioning procedure. In addition, activation of $\mathrm{CB} 1$ receptor transmission or inhibition of the endocannabinoid reuptake within BLA strongly potentiated the acquisition of fear memory. Moreover, fear memory formation, mediated by $\mathrm{CB} 1$ receptor, was blocked when the medial prefrontal cortex (mPFC) was pharmacologically inactivated before intra-BLA activation of CB1. These findings are consistent with the report presented by Campolongo et al., which showed that intra-BLA activation of CB1 receptors can potentiate the encoding of associative memory for IA learning [82]. Previous studies conducted by Roche et al. [96] indicated that intra-BLA blockade of CB1 receptor transmission with rimonabant inhibits the formation of contextdependent fear memory. Overall, the previously mentioned findings suggest that $\mathrm{CB} 1$ receptor-dependent transmission within the BLA can influence the magnitude of emotional memory encoding. Additionally, the memory-improving effects of AM251 observed in this study were in agreement with the results obtained by Riedel and Davies [97]. They have reported that while the $\mathrm{CB} 1$ receptor agonists impair memory formation, the $\mathrm{CB} 1$ receptor antagonists reverse these deficits or act as memory enhancers.

Lin et al. studied the effects of another CB1 receptor antagonist AM281 on the formation of contextual fear memory in adult mice [98]. AM281 $(2.5 \mathrm{mg} / \mathrm{kg})$ was injected both intraperitoneally and intra-hippocampally to assess the influence on memory acquisition. These results indicate that CB1 receptormediated signaling within the area of hippocampus negatively regulates the acquisition in contextual fear memory task. Thus, AM281 seems to be a good candidate for memory enhancement; however, further studies in animal models of cognitive dysfunctions are still required. In the context of this subject, it should be noted that Wise et al. decided to determine the effects of a relatively novel and potent $\mathrm{CB} 1$ receptor antagonist $\mathrm{CE}$ on memory processes. $\mathrm{CE}$ is structurally distinct from rimonabant. Wise and colleagues observed that CE significantly enhanced memory consolidation in the RAM procedure [99].

As we described previously, the influence of the CB1 receptor ligands on memory and learning processes has been widely documented by various experiments and clinical studies. Although CB1 receptor ligands are able to improve as well as to impair memory, each of them affects memory in a different way. Such contradictory findings may be connected with differences in behavioral tasks used, handling procedures, e.g., time of drug administration, the kind of drug treatment, or other experimental conditions, as well as doses and $\mathrm{CB}$ compounds selected. Therefore, future studies may help to discover and describe the precise role and character of different CB1 receptor compounds (Table 2).

\section{The Role of CB Receptor in the Memory-Related Responses in Animal Models of Memory: CB2 Receptor Agents}

The specific impact of $\mathrm{CB} 2$ receptor ligands on the cognitionrelated processes seems to be more complex and still not precisely explored. In this part of the present elaboration, we can discuss only few results concerning the effects of the CB2 receptor ligands on memory and learning.

The results of the studies suggest that the activation of CB2 receptors evokes diverse effects depending on the brain area. Chronic stimulation of $\mathrm{CB} 2$ receptors in the hippocampus increases excitatory synaptic transmission [26], and simultaneously, deletion of CB2 in the same brain structure leads to reduction in dendritic spine density [25]. Chronic activation of CB2 also increases GABA-A receptor expression [28], yet it does not affect the inhibitory synaptic transmission in the hippocampus. CB2 receptor agonists reduce membrane excitability of cortical neurons [35] leaving hippocampal neurons unaffected [26]. CB2 receptor agonists also increase chloride conductance [35].

JWH133 is a selective CB2 receptor agonist. Kruk-Slomka et al. [64] established that the lower dose of JWH133 $(0.5 \mathrm{mg} / \mathrm{kg})$ exerted no influence on the acquisition but enhanced the consolidation of long-term memory in the PA test. JWH133 (at higher doses of 1.0 and $2.0 \mathrm{mg} / \mathrm{kg}$ ) improved the acquisition or consolidation of long-term memory. An acute pretraining and post-training administration improved memory-related responses evaluated in the PA test.

The CB2 antagonist AM630 is one of the most studied exogenous $\mathrm{CB}$ receptor ligands. It acts as an inverse agonist both at CB2 and CB1 receptor sites [100]. Kruk-Slomka et al. [64] revealed that AM630 significantly improved memory. The higher doses of AM630 (2.0 and $3.0 \mathrm{mg} / \mathrm{kg}$ ) induced statistically significant increase in antioxidant properties of brain tissue and evoked long-term memory improvement in behavioral test. However, the lower dose $(0.5 \mathrm{mg} / \mathrm{kg})$ was found inactive; it does not alter memory-related responses in the PA test in mice.

It has been revealed in behavioral studies described previously that both a selective CB2 receptor agonist JWH133 and a competitive CB2 receptor antagonist AM630 significantly improved long-term memory acquisition and consolidation in the PA test [64]. In contrast to these findings, García-Gutiérrez 
Table 2 The chemical structure of CB1 receptor ligands

\section{CB1 receptor agonists}

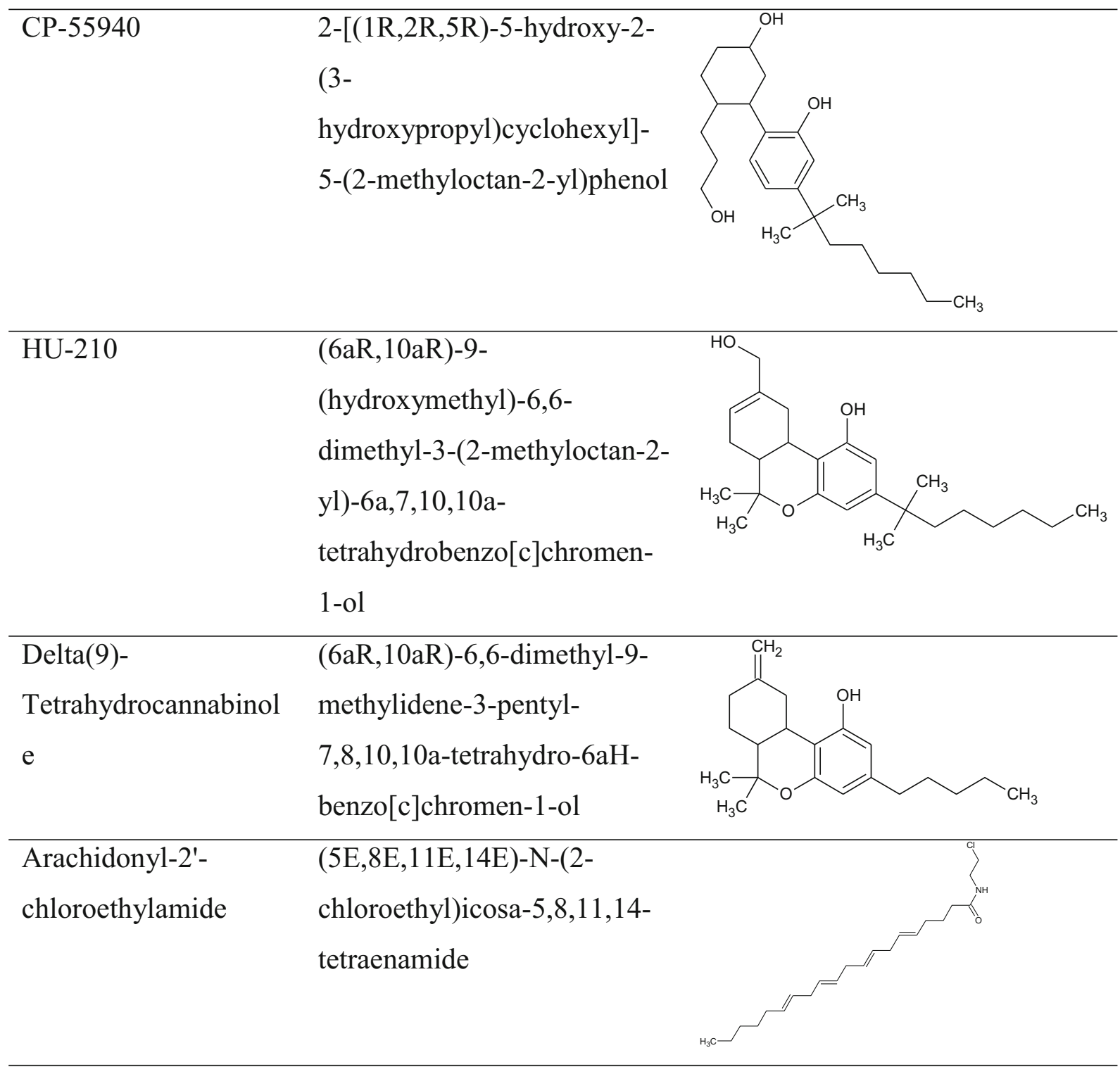

\section{CB1 receptor antagonists}

$\begin{array}{ll}\mathrm{CE} & \text { 1-[7-(2-Chlorophenyl)-8-(4- } \\ & \text { chlorophenyl)-2- } \\ & \text { methylpyrazolo[1,5-a]-[1,3,5] } \\ & \text { triazin-4-yl]-3- } \\ & \text { ethylaminoazetidine-3- } \\ & \text { carboxylic acid amide } \\ & \text { benzenesulfonate }\end{array}$


Table 2 (continued)

\begin{tabular}{|c|c|}
\hline $\begin{array}{l}\text { Rimonabant, } \\
\text { SR141716A }\end{array}$ & $\begin{array}{l}\text { 5-(4-chlorophenyl)-1-(2,4- } \\
\text { dichlorophenyl)-4-methyl-N- } \\
\text { piperidin-1-ylpyrazole-3- } \\
\text { carboxamide }\end{array}$ \\
\hline $\begin{array}{l}\text { Surinabant, } \\
\text { SR } 147778\end{array}$ & $\begin{array}{l}\text { 5-(4-bromophenyl)-1-(2,4- } \\
\text { dichlorophenyl)-4-ethyl-N- } \\
\text { piperidin-1-ylpyrazole-3- } \\
\text { carboxamide }\end{array}$ \\
\hline AM251 & $\begin{array}{l}\text { 1-(2,4-dichlorophenyl)-5-(4- } \\
\text { iodophenyl)-4-methyl-N- } \\
\text { piperidin-1-ylpyrazole-3- } \\
\text { carboxamide }\end{array}$ \\
\hline AM281 & $\begin{array}{l}\text { 1-(2,4-dichlorophenyl)-5-(4- } \\
\text { iodophenyl)-4-methyl-N- } \\
\text { morpholin-4-ylpyrazole-3- } \\
\text { carboxamide }\end{array}$ \\
\hline
\end{tabular}

\section{CB1/CB2 receptors agonists}

WIN-55212-2
(11R)-2-methyl-11-
(naphthalene-1-carbonyl)-9-
oxa-1-
azatricyclo[6.3.1.0 $\left.{ }^{4},{ }^{12}\right]$ dodeca
-2,4(12),5,7-tetraene

et al. [25] have shown that JWH133 enhanced memory consolidation, but AM630 impaired memory-related responses in the step-down IA test.
The enhancement of memory caused by both CB2 antagonist and CB2 agonist obtained by Kruk-Slomka et al. [64] may be connected with pharmacokinetic properties of used CB2 
receptor ligands, i.e., JWH133 and AM630. It needs to be underlined that a CB2-selective agent AM630 acts as an inverse agonist rather than as a "silent" antagonist. The inverse efficacy at $\mathrm{CB} 2$ receptors and the $\mathrm{CB} 2 / \mathrm{CB} 1$ affinity ratio has been indicated for AM630 (CB2/CB1 affinity = 165); therefore, AM630 has been found to act as a low-affinity partial agonist in some experiments but as a low-potency inverse agonist in another study [101]. The pharmacological properties of AM630 are more complex. It has been revealed that AM630 acts as an inverse agonist at CB2 receptors as well as an inverse agonist at $\mathrm{CB} 1$ receptors [102]; therefore, it may be proposed that both agonist and antagonist of $\mathrm{CB} 2$ receptors used in this study may improve memory and learning processes through CB1 as well as CB2 receptors. Further experiments are required to explain this phenomenon.

To sum up, it should be mentioned that the specific impact of $\mathrm{CB} 2$ receptor ligands on the cognition-related processes seems to be more complex and still not precisely evaluated. Similarly as CB1 receptor ligands, CB2 receptor ligands are able to attenuate as well as facilitate memory and learning processes. These different memory effects may be associated mainly with pharmacokinetic properties of tested CB2 receptor ligands as well as with antioxidant properties, exhibited by both agonists and antagonist of these receptors (Table 3).

\section{The Role of CB Receptor in the Memory-Related Responses in Animal Models of Memory: CB Receptor Deficiency}

In order to establish the role of $\mathrm{CB}$ receptors more accurate and disentangle the role of endocannabinoid system in memory formation, two strands of research have been implemented: knockout mice deficient for $\mathrm{CB}$ receptor as well as aforementioned administration of selective $\mathrm{CB}$ receptor antagonist.

Litvin et al. used a genetic knockout of CB1 receptors (CB1KOS) in order to evaluate the role of these receptors in memory formation processes [9]. The CB1KOS and the animals that received the CB1 antagonist AM251 showed enhanced levels of social memory relative to their respective controls in a social discrimination test. These results emphasize the role of $\mathrm{CB} 1$ receptors in memory formation. The endocannabinoids bind to $\mathrm{CB} 1$ receptors in various brain regions to modulate behavioral functions in relation to cognition, emotionality, and stress [12, 103]. These results delineate the effects of $\mathrm{CB} 1$ receptor inactivation by utilizing convergent genetic and pharmacological approaches. These paths of experiments produce similar behavioral profiles resulting in enhancing memory acquisition in the social discrimination test with some differences, which can attest to discrepancies between these manipulations. These results extend the role of the ECS in mood and memory [104] and simultaneously are in line with the reports describing a specific role of $\mathrm{CB} 1$ receptor in these processes [105]. The results achieved by Litvin et al. [9] of increased cognitive abilities in the CB1KOS mice are consistent with the previous reports describing enhanced cognitive performance in several other tests like active avoidance memory [106], CFC [107], and ORT [108, 109]. It has been also reported that $\mathrm{CB} 1$-deficient mice display normal acquisition and impaired extinction of both spatial reference memory $[110,111]$ and cued fear memory [59]. CB1KOS mice also present reduced working memory [58]. Although the parameters of PA concerning the memory-related effects stayed unaffected [36], the contextual fear memory was reported both to be enhanced and to be impaired [56].

Similarly, for a complete understanding of the mechanism underlying the action of $\mathrm{CB} 2$ receptors, it will be necessary to determine the role of $\mathrm{CB} 2$ receptors in regulating various properties of synaptic transmission. It also needs to be evaluated whether the affected immune functions in $\mathrm{CB} 2$ receptor genetic knockout mice (CB2KOS) influence the processes involved in learning and memory. Li and Kim [112] utilized both $\mathrm{CB} 2$-deficient mice and acute blockade of $\mathrm{CB} 2$ receptors by AM630. The results indicated that the inhibition of $\mathrm{CB} 2$ by a specific CB2 receptor antagonist AM630 had no effect on memory acquisition in contrast to the knockout of CB2 receptors. The findings indicated that acquisition of spatial working memory evaluated in Y-maze in CB2KOS was enhanced in comparison to mice examined in the WMT. The results also indicated that $\mathrm{CB} 2$ receptors play diverse roles in regulating memory. Thus, taken together, the results imply that the effects of CB2 receptor blockade (either through genetic deficiency or pharmacological inhibition) are variable. Acute blockade with AM630 exerts no effect on memory acquisition, implying that downregulation of $\mathrm{CB} 2$ receptors needs to be prolonged to induce such effects [112].

These all findings indicate that normal acquisition of cued fear memory is common for both CB1- and CB2-deficient mice, but alterations in the working memory are opposite. Overall, conclusion leads to the statement that CB1 and CB2 receptors play a role in modulation of memory processes. Once the role of each type of receptor is fully characterized, either $\mathrm{CB} 1$ or $\mathrm{CB} 2$ receptor can be selectively targeted for pharmacological therapeutics to induce the desired results and avoid the unwanted ones.

\section{The Role of Endocannabinoids in the Memory-Related Responses in Animal Models of Memory}

As we mentioned previously, AEA and 2-AG are two main endocannabinoids in the CNS. Lin et al. [2011] examined the impact of AM404, an AEA reuptake inhibitor, on the acquisition of memory in mice using the CFC paradigm [98]. AM404 was administered into the dorsal hippocampus 
Table 3 The chemical structure of CB2 receptor ligands

\section{CB2 receptor agonists}

JWH 015

CB2 receptor antagonists

Iodopravadoline, AM630

\author{
[6-iodo-2-methyl-1-(2- \\ morpholin-4-ylethyl)indol-3- \\ yl]-(4- \\ methoxyphenyl)methanone
}

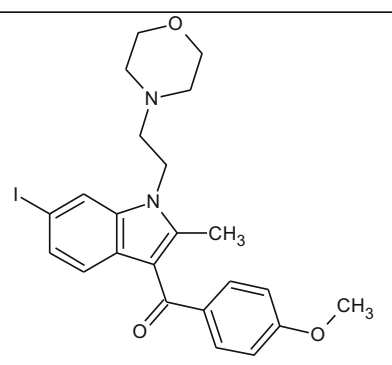

15 min prior to the conditioning session. The outcome of the experiment indicated significant suppression of the fear memory. Moreover, Lin et al. [98] confirmed that the inhibitory effect of AM404 on fear memory formation was mediated by the activation of $\mathrm{CB} 1$ receptor. Taken together, they concluded that AEA-mediated activation of $\mathrm{CB} 1$ receptor contributes negatively to the acquisition of contextual fear memory.

The level of AEA may be also increased by the usage of FAAH inhibitor. FAAH inhibitor, URB597, increases AEA levels at those neuronal sites and regions of the brain, where AEA is synthesized and released, producing a neuron-specific activation of $\mathrm{CB} 1$ receptor in those areas. On the contrary, systemic administration of $\mathrm{CB} 1$ receptor agonist such as $\triangle 9$-THC produces global activation of all CB1 receptors in the whole brain [68].

Mazzola et al. [68] accomplished the inhibition of FAAH by administering URB597 [68]. The effects of URB597 were studied both alone and after pretreatment with rimonabant in the PA paradigm. The findings of this study revealed that
URB597 (0.1-1.0 mg/kg), injected $40 \mathrm{~min}$ before the learning trial, had a significant enhancing effect on memory acquisition. Further testing demonstrated that the memory-enhancing effects were inhibited after the pretreatment with $1.0 \mathrm{mg} / \mathrm{kg}$ rimonabant. These results are consistent with the previous studies suggesting that FAAH inhibition enhances place memory acquisition in the WMT procedure [113]. The effects of URB597 on acquisition were also studied [114]. In this experiment, the authors evaluated the effects and interaction between URB597 and WIN 55,212-2 using the PA test [114]. Learning and memory impairment was elicited by WIN $55,212-2(1.0 \mathrm{mg} / \mathrm{kg})$ administered $30 \mathrm{~min}$ before the acquisition trial in rats. URB597 $(0.1,0.3,1.0 \mathrm{mg} / \mathrm{kg})$ or SR141716A $(1.0 \mathrm{mg} / \mathrm{kg})$ was injected $10 \mathrm{~min}$ before WIN 55,212-2 or URB597, respectively. The results indicated that URB597 at the dose of 0.3 and $1 \mathrm{mg} / \mathrm{kg}$ enhanced memory acquisition in the PA test. The dose of $0.1 \mathrm{mg} / \mathrm{kg}$ exerted no effects. The cognitive-enhancing effects were blocked by SR141716A. This study also revealed that SR141716A 
injected separately had no effects on cognition. In conclusion, these findings suggest that URB597 has potential to protect against memory deficits produced by CBs. The results of this study are in accordance with the other studies in which stimulation of the endogenous CB signaling with URB597 enhances acquisition in the PA learning and aversively reinforced spatial memory tasks $[68,86,113]$.

As CB1 agonists exert amnestic effects and URB597 increases endogenous level of $\mathrm{CB} 1$ agonist AEA, findings that URB597 enhances memory and this improvement can be inhibited by $\mathrm{CB} 1$ receptor antagonist are puzzling. It is possible that learning improvement produced by FAAH inhibitor is not actually mediated by $\mathrm{CB} 1$ receptor but is blocked by SR141716A due to its inverse agonist effects on CB1 receptor.

De Oliveira et al. investigated the role of AEA upon the different phases of memory processing [37]. The results were evaluated in the step-down IA task. The findings of the study indicated that post-training infusion of anandamide facilitated memory consolidation. It is worth noting that only the small dose of AEA infused into the dorsal hippocampus of the male Wistar rats exerted enhancing effect on memory. Any memory-enhancing effect was observed after the administration of higher doses. The lack of its efficacy at higher doses may be explained by its binding to different areas. At the low dose, AEA may mainly target the $\mathrm{CB} 1$ receptors.

It should also be noted that the effects of FAAH inhibitor, OL-135, and of genetic deletion of FAAH in mice were studied [115]. Both of these manipulations enhanced the acquisition of spatial learning in the WMT. This enhancement was inhibited by pretreatment with rimonabant, suggesting the role of CB1 receptors in the observed effects [113, 115, 116].

The research concerning FAAH inhibition opens a new approach for developing medications that act indirectly by enhancing the actions of endogenous lipid amide mediators,

Table 4

The chemical structure of reuptake inhibitors of endocannabinoids

\section{Re-uptake inhibitors}

AM404 $5 \mathrm{Z}, 8 \mathrm{Z}, 11 \mathrm{Z}, 14 \mathrm{Z})-\mathrm{N}-(4-$
hydroxyphenyl)icosa-
5,8,11,14-tetraenamide
URB597

JZL184

(4-nitrophenyl) 4-[bis(1,3-

benzodioxol-5-yl)-

hydroxymethyl]piperidine-1-

carboxylate

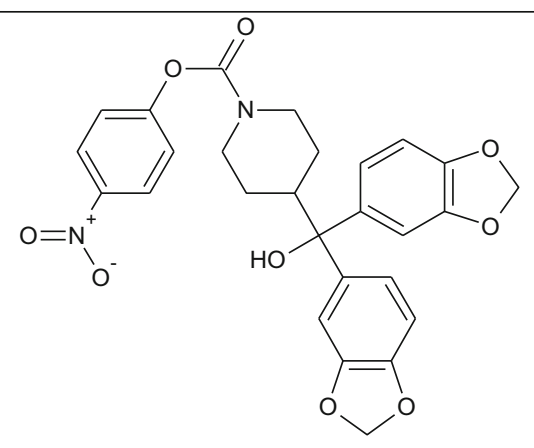

OL-135

7-phenyl-1-(5-pyridin-2-yl-

1,3-oxazol-2-yl)heptan-1-one

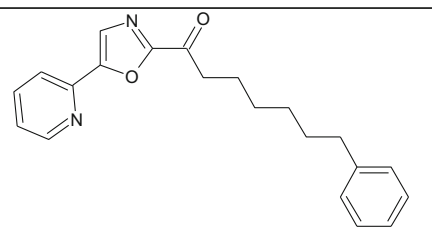


where they are synthesized and released. It is worth mentioning that FAAH inhibition might be related to a wide spectrum of therapeutic actions and could also share some of the adverse effects of cannabis; therefore, it is prominent that URB597 possesses potentially beneficial properties and displays no indication of liability for abuse or dependence. Therefore, it has been suggested to improve therapeutic interventions in memory deficit cases (Table 4).

\section{Conclusion}

The results of the studies described in this elaboration summarize the impact of CBs on different stages of memory formation. Many preclinical studies have evaluated the multidirectional effects of compounds that directly affect the functioning of the ECS (CB receptor ligands), as well as compounds that modulate this function indirectly (inhibitors that degrade endocannabinoids in the brain).

The modulation of the influence of the $\mathrm{CB}$ receptor ligands on the different memory stages was widely evaluated in the behavioral studies. Although both $\mathrm{CB} 1$ and $\mathrm{CB} 2$ receptor ligands are able to improve as well as to impair memory, each of them affects memory in a different way and this subject is still unexplored. Thus, further studies, not only behavioral experiments, but also molecular (e.g., the assessment of the density of the $\mathrm{CB}$ receptors in different brain areas: hippocampus, prefrontal cortex) and biochemical (e.g., the influence of CB receptor ligands on the neurotransmitter and metalloproteinase levels in the brain or on the oxidative stress biomarkers) are necessary. The results from these interdisciplinary experiments may provide new information concerning the therapeutically beneficial properties of the ECS in the brain.

\section{Compliance with Ethical Standards}

Conflict of Interest The authors declare that they have no conflict of interest.

Open Access This article is distributed under the terms of the Creative Commons Attribution 4.0 International License (http:// creativecommons.org/licenses/by/4.0/), which permits unrestricted use, distribution, and reproduction in any medium, provided you give appropriate credit to the original author(s) and the source, provide a link to the Creative Commons license, and indicate if changes were made.

\section{References}

1. Fernández-Ruiz J, Berrendero F, Hernández ML, Ramos JA (2000) The endogenous cannabinoid system and brain development. Trends Neurosci 23(1):14-20

2. Fride E (2008) Multiple roles for the endocannabinoid system during the earliest stages of life: pre- and postnatal development. J Neuroendocrinol 1:75-81
3. Harkany T, Guzmán M, Galve-Roperh I, Berghuis P, Devi LA, Mackie K (2007) The emerging functions of endocannabinoid signaling during CNS development. Trends Pharmacol Sci 28(2):83-92

4. Bialuk I, Winnicka MM (2011) AM251, cannabinoids receptor ligand, improves recognition memory in rats. Pharmacol Rep 63(3):670-679

5. Goodman J, Packard MG (2015) The influence of cannabinoids on learning and memory processes of the dorsal striatum. Neurobiol Learn Mem 125:1-14

6. Koppel J, Davies P (2008) Targetting the endocannabinoid system in Alzheimer's disease. J Alz Dis 15(3):495-504

7. Busquets-Garcia A, Puighermanal E, Pastor A, De la Torre R, Maldonado R, Ozaita A (2011) Differential role of anandamide and 2-arachidonoylglycerol in memory and anxiety-like responses. Biol Psychiatry 70(5):479-486

8. Morena M, Campolongo P (2014) The endocannabinoid system: an emotional buffer in the modulation of memory function. Neurobiol Learn Mem 112:30-43

9. Litvin Y, Phan A, Hill MN, Pfaff DW, McEwen BS (2013) CB1 receptor signaling regulates social anxiety and memory. Genes Brain Behav 12(5):479-489

10. Srivastava RK, Lutz B (2012) Dysregulation of hypothalamicpituitary-adrenal axis in mice lacking CB1 receptor in adrenergic and noradrenergic neurons. 22nd Annual Symposium of the International Cannabinoid Research Society. Freiburg, Germany

11. Tzavara ET, Davis RJ, Perry KW, Li X, Salhoff C, Bymaster FP, Witkin JM, Nomikos GG (2003) The CB1 receptor antagonist SR141716A selectively increases monoaminergic neurotransmission in the medial prefrontal cortex: implications for therapeutic actions. Br J Pharmacol 138:544-553

12. Hill MN, Patel S, Campolongo P, Tasker JG, Wotjak CT, Bains JS (2010b) Functional interactions between stress and the endocannabinoid system: from synaptic signaling to behavioral output. J Neurosci 30:14980-14986

13. Lafenetre P, Chaouloff F, Marsicano G (2007) The endocannabinoid system in the processing of anxiety and fear and how CB1 receptors may modulate fear extinction. Pharmacol Res 56:367-381

14. Martin M, Ledent C, Parmentier M, Maldonado R, Valverde O (2002) Involvement of CB1 cannabinoid receptors in emotional behaviour. Psychopharmacology 159:379-387

15. Metna-Laurent M, Soria-Gomez E, Verrier D, Conforzi M, Jego P, Lafenetre P, Marsicano G (2012) Bimodal control of fear-coping strategies by $\mathrm{CB}(1)$ cannabinoid receptors. J Neurosci 32:71097118

16. Steiner MA, Wotjak CT (2008) Role of the endocannabinoid system in regulation of the hypothalamic-pituitary-adrenocortical axis. Prog Brain Res 170:397-432

17. Trezza V, Campolongo P (2013) The endocannabinoid system as a possible target to treat both the cognitive and emotional features of post-traumatic stress disorder (PTSD). Front Behav Neurosci 7: 100

18. Morena M, Roozendaal B, Trezza V, Ratano P, Peloso A, Hauer D, Atsak P, Trabace L et al (2014) Endogenous cannabinoid release within prefrontal-limbic pathways affects memory consolidation of emotional training. Proc Natl Acad Sci U S A 111(51):1833318338

19. Ruiz-Valdepeñas L, Martínez-Orgado JA, Benito C, Millán Á, Tolón RM, Romero JJ (2011) Cannabidiol reduces lipopolysaccharide-induced vascular changes and inflammation in the mouse brain: an intravital microscopy study. J Neuroinflammation 8(1):5

20. Ishiguro H, Horiuchi Y, Ishikawa M, Koga M, Imai K, Suzuki Y, Morikawa M, Inada T et al (2010) Brain cannabinoid CB2 receptor in schizophrenia. Biol Psychiatry 67(10):974-982 
21. Tong D, He S, Wang L, Jin L, Si P, Cheng X (2013) Association of single-nucleotide polymorphisms in the cannabinoid receptor 2 gene with schizophrenia in the Han Chinese population. J Mol Neurosci 51(2):454-460

22. Onaivi ES, Ishiguro H, Gong JP, Patel S, Meozzi PA, Myers L, Perchuk A, Mora Z et al (2008) Brain neuronal CB2 cannabinoid receptors in drug abuse and depression: from mice to human subjects. PLoS One 3(2):e1640

23. Minocci D, Massei J, Martino A, Milianti M, Piz L, Di Bello D, Sbrana A, Martinotti E et al (2011) Genetic association between bipolar disorder and 524A $>\mathrm{C}$ (Leu133Ile) polymorphism of CNR2 gene, encoding for CB2 cannabinoid receptor. J Affect Disord 134(1-3):427-430

24. Ortega-Alvaro A, Aracil-Fernández A, García-Gutiérrez MS, Navarrete F, Manzanares J (2011) Deletion of CB2 cannabinoid receptor induces schizophrenia-related behaviors in mice. Neuropsychopharmacology 36(7):1489-1504

25. García-Gutiérrez MS, Ortega-Álvaro A, Busquets-García A, Pérez-Ortiz JM, Caltana L, Ricatti MJ, Brusco A, Maldonado R et al (2013) Synaptic plasticity alterations associated with memory impairment induced by deletion of CB2 cannabinoid receptors. Neuropharmacology 73:388-396

26. Kim J, Li Y (2015) Chronic activation of CB2 cannabinoid receptors in the hippocampus increases excitatory synaptic transmission. J Physiol 593(4):871-886

27. Andó RD, Bíró J, Csölle C, Ledent C, Sperlágh B (2012) The inhibitory action of exo- and endocannabinoids on $[3 \mathrm{H}] \mathrm{GABA}$ release are mediated by both $\mathrm{CB} 1$ and $\mathrm{CB} 2$ receptors in the mouse hippocampus. Neurochem Int 60(2):145-152

28. García-Gutiérrez MS, García-Bueno B, Zoppi S, Leza JC, Manzanares J (2012) Chronic blockade of cannabinoid CB2 receptors induces anxiolytic-like actions associated with alterations in GABA-A receptors. Brit J Pharmacol 165(4):951-964

29. Morgan NH, Stanford IM, Woodhall GL (2009) Functional CB2 type cannabinoid receptors at CNS synapses. Neuropharmacology 57(4):356-368

30. Anand P, Whiteside G, Fowler CJ, Hohmann AG (2009) Targeting CB2 receptors and the endocannabinoid system for the treatment of pain. Brain Res Rev 60(1):255-266

31. Navarrete F, Pérez-Ortiz JM, Manzanares J (2012) Cannabinoid CB2 receptor-mediated regulation of impulsive-like behaviour in DBA/2 mice. Brit J Pharmacol 165(1):260-273

32. Valenzano KJ, Tafesse L, Lee G, Harrison JE, Boulet JM, Gottshall SL, Mark L, Pearson MS et al (2005) Pharmacological and pharmacokinetic characterization of the cannabinoid receptor 2 agonist, GW405833, utilizing rodent models of acute and chronic pain, anxiety, ataxia and catalepsy. Neuropharmacology 48(5): $658-672$

33. Xi ZX, Peng XQ, Li X, Song R, Zhang HY, Liu QR, Yang HJ, Bi GH et al (2011) Brain cannabinoid CB2 receptors modulate cocaine's actions in mice. Nat Neurosci 14(9):1160-1166

34. Van Sickle MD, Duncan M, Kingsley PJ, Mouihate A, Urbani P, Mackie K, Stella N, Makriyannis A et al (2005) Neuroscience: identification and functional characterization of brainstem cannabinoid CB2 receptors. Science 310(5746):329-332

35. den Boon FS, Chameau P, Schaafsma-Zhao Q, van Aken W, Bari M, Oddi S, Kruse CG, Maccarrone M et al (2012) Excitability of prefrontal cortical pyramidal neurons is modulated by activation of intracellular type- 2 cannabinoid receptors. Proc Nat Acad Sci USA 109(9):3534-3539

36. Zimmer A, Zimmer AM, Hohmann AG, Herkenham M, Bonner TI (1999) Increased mortality, hypoactivity, and hypoalgesia in cannabinoid CB1 receptor knockout mice. Proc Natl Acad Sci U S A 96(10):5780-5785

37. De Oliveira AL, Genro BP, Diehl F, Quillfeldt JA (2008) Differential role of the hippocampal endocannabinoid system in the memory consolidation and retrieval mechanisms. Neurobiol Learn Mem 90:1-9

38. Johns DG, Behm DJ, Walker DJ, Ao Z, Shapland EM, Daniels DA, Riddick M, Dowell S et al (2007) The novel endocannabinoid receptor GPR55 is activated by atypical cannabinoids but does not mediate their vasodilator effects. Br J Pharmacol 152(5):825-831

39. Klein TW (2005) Cannabinoid-based drugs as anti-inflammatory therapeutics. Nat Rev Immunol 5:400-411

40. Barzegar S, Komaki A, Shahidi S, Sarihi A, Mirazi N, Salehi I (2015) Effects of cannabinoid and glutamate receptor antagonists and their interactions on learning and memory in male rats. Pharmacol Biochem Behav 131:87-90

41. Godlewski G, Offertáler L, Wagner JA, Kunos G (2009) Receptors for acylethanolamides-GPR55 and GPR119. Prostaglandins Other Lipid Mediat 89:105-111

42. Sawzdargo M, Nguyen T, Lee DK, Lynch KR, Cheng R, Heng $\mathrm{HH}$, George SR, O’Dowd BF (1999) Identification and cloning of three novel human $\mathrm{G}$ protein-coupled receptor genes GPR52, PsiGPR53 and GPR55: GPR55 is extensively expressed in human brain. Brain Res Mol Brain Res 64(2):193-198

43. Henstridge CM, Balenga NA, Kargl J, Andradas C, Brown AJ, Irving A, Sanchez C, Waldhoer M (2011) Minireview: recent developments in the physiology and pathology of the lysophosphatidylinositolsensitive receptor GPR55. Mol Endocrinol 25(11):1835-1848

44. Ryberg E, Larsson N, Sjögren S, Hjorth S, Hermansson NO, Leonova J, Elebring T, Nilsson K et al (2007) The orphan receptor GPR55 is a novel cannabinoid receptor. Br J Pharmacol 152: 1092-1101

45. Oka S, Toshida T, Maruyama K, Nakajima K, Yamashita A, Sugiura T (2009) 2-Arachidonoyl-sn-glycero-3-phosphoinositol: a possible natural ligand for GPR55. J Biochem 145:13-20

46. Henstridge CM, Balenga NA, Ford LA, Ross RA, Waldhoer M, Irving AJ (2009) The GPR55 ligand L-alpha-lysophosphatidylinositol promotes RhoA-dependent $\mathrm{Ca} 2+$ signaling and NFAT activation. FASEB J 23(1):183-193

47. Oka S, Nakajima K, Yamashita A, Kishimoto S, Sugiura T (2007) Identification of GPR55 as a lysophosphatidylinositol receptor. Biochem Biophys Res Commun 362(4):928-934

48. Ross RA (2009) The enigmatic pharmacology of GPR55. Trends Pharmacol Sci 30(3):156-163

49. Chu ZL, Carroll C, Alfonso J, Gutierrez V, He H, Lucman A, Pedraza M, Mondala $\mathrm{H}$ et al (2008) A role for intestinal endocrine cell-expressed G protein-coupled receptor 119 in glycemic control by enhancing glucagon-like peptide- 1 and glucose-dependent insulinotropic peptide release. Endocrinology 149:2038-2047

50. Lauffer LM, Lakoubov R, Brubaker PL (2009) GPR119 is essential for oleoylethanolamide-induced glucagon-like peptide-1 secretion from the intestinal enteroendocrine L-cell. Diabetes 58: 1058-1066

51. Overton HA, Fyfe MC, Reynet C (2008) GPR119, a novel G protein-coupled receptor target for the treatment of type 2 diabetes and obesity. Br J Pharmacol 153(1):76-81

52. Ameri A (2009) The effects of cannabinoids on the brain. Prog Neurbiol 58:315-348

53. Calignano A, La Rana G, Giuffrida A, Piomelli D (1998) Control of pain initiation by endogenous cannabinoids. Nature (Lond) 394:277-281

54. Di Marzo V, Goparaju SK, Wang L, Liu J, Batkai S, Jarai Z, Fezza F, Miura GI et al (2001) Leptin-regulated endocannabinoids are involved in maintaining food intake. Nature (Lond) 410:822-825

55. Grotenhermen F (2004) The pharmacology of cannabinoids. Neuro Endocrinol Lett 25(1/2):14-23

56. Hughes RN (2004) The value of spontaneous alternation behavior $(\mathrm{SAB})$ as a test of retention in pharmacological investigations of memory. Neurosci Biobehav Rev 28(5):497-505 
57. Iversen LL (2000) The science of marijuana (review book). Oxford University Press, Oxford

58. Ledent C, Valverde O, Cossu G, Petitet F, Aubert JF, Beslot F, Böhme GA, Imperato A et al (1999) Unresponsiveness to cannabinoids and reduced addictive effects of opiates in CB1 receptor knockout mice. Science 283(5400):401-404

59. Marsicano G, Goodenough S, Monory K, Hermann H, Eder M, Cannich A, Azad SC, Cascio MG et al (2003) CB1 cannabinoid receptors and on-demand defense against excitotoxicity. Science (Wash DC) 302:84-88

60. Riebe CJ, Wotjak CT (2011) Endocannabinoids and stress. Stress 14:384-397

61. Terranova JP, Storme JJ, Lafon N, Pério A, Rinaldi-Carmona M, Le Fur G, Soubrié P (1996) Improvement of memory in rodents by the selective CB1 cannabinoid receptor antagonist, SR 141716. Psychopharmacology 126(2):165-172

62. Bohme GA, Laville M, Ledent C, Parmentier M, Imperato A (2000) Enhanced long-term potentiation in mice lacking cannabinoid CB1 receptors. Neuroscience 95(1):5-7

63. Kruk-Slomka M, Boguszewska-Czubara A, Slomka T, Budzynska B, Biala G (2016a) Correlations between the memory-related behavior and the level of oxidative stress biomarkers in the mice brain, provoked by an acute administration of CB receptor ligands. Neural Plast. doi:10.1155/2016/9815092

64. Kruk-Slomka M, Biala G (2016) CB1 receptors in the formation of the different phases of memory-related processes in the inhibitory avoidance test in mice. Behav Brain Res 301:84-95

65. Puighermanal E, Busquets-Garcia A, Maldonado R, Ozaita A (2012) Cellular and intracellular mechanisms involved in the cognitive impairment of cannabinoids. Philos Trans R Soc Lond Ser B Biol Sci 367(1607):3254-3263

66. Zarrindast MR, Navaeian M, Nasehi M (2011) Influence of threeday morphine-treatment upon impairment of memory consolidation induced by cannabinoid infused into the dorsal hippocampus in rats. Neurosci Res 69(1):51-59

67. Abush H, Akirav I (2010) Cannabinoids modulate hippocampal memory and plasticity. Hippocampus 20(10):1126-1138

68. Mazzola C, Medalie J, Scherma M, Panlilio LV, Solinas M, Tanda G, Drago F, Cadet JL et al (2009) Fatty acid amide hydrolase (FAAH) inhibition enhances memory acquisition through activation of PPAR-alpha nuclear receptors. Learn Mem 16:332-337

69. Pamplona FA, Takahashi RN (2006) WIN55,212-2 impairs contextual fear conditioning through the activation of CB1 cannabinoid receptors. Neurosci Lett 397:88-92

70. Schneider M, Schömig E, Leweke FM (2008) Acute and chronic cannabinoid treatment differentially affects recognition memory and social behavior in pubertal and adult rats. Addict Biol 13: 345-357

71. Wise LE, Long KA, Abdullah RA, Long JZ, Cravatt BF, Lichtman AH (2012) Dual fatty acid amide hydrolase and monoacylglycerol lipase blockade produces THC-like Morris water maze deficits in mice. ACS Chem Neurosci 3(5):369-378

72. Campolongo P, Ratano P, Manduca A, Scattoni ML, Palmery M, Trezza V, Cuomo V (2012) The endocannabinoid transport inhibitor AM404 differentially modulates recognition memory in rats depending on environmental aversiveness. Front Behav Neurosci 6:11

73. Kim JJ, Fanselow M (1992) Modality-specific retrograde amnesia of fear. Science 256:675-676

74. Phillips RG, LeDoux JE (1992) Differential contribution of amygdala and hippocampus to cued and contextual fear conditioning. Behav Neurosci 106:274-285

75. Marchalant Y, Cerbai F, Brothers HM, Wenk GL (2008) Cannabinoid receptor stimulation is anti-inflammatory and improves memory in old rats. Neurobiol Aging 29(12):1894-1901

76. Clarke JR, Rossato JI, Monteiro S, Bevilaqua LRM, Izquierdo I, Cammarota M (2008) Posttraining activation of CB1 cannabinoid receptors in the CA1 region of the dorsal hippocampus impairs object recognition long-term memory. Neurobiol Learn Mem 90: 374-381

77. Maćkowiak M, Chocyk A, Dudys D, Wedzony K (2009) Activation of CB1 cannabinoid receptors impairs memory consolidation and hippocampal polysialylated neural cell adhesion molecule expression in contextual fear conditioning. Neuroscience 158(4):1708-1716

78. Yim TT, Hong NS, Ejaredar M, McKenna JE, McDonald RJ (2008) Post-training CB1 cannabinoid receptor agonist activation disrupts long-term consolidation of spatial memories in the hippocampus. Neuroscience 151:929-936

79. Arenos JD, Musty RE, Bucci DJ (2006) Blockade of cannabinoid CB1 receptors alters contextual learning and memory. Eur J Pharmacol 539:177-183

80. De Oliveira A, Genro BP, Breda RV, Pedroso MF, Da Costa JC, Quillfeldt JA (2006) AM251, a selective antagonist of the CB1 receptor, inhibits the induction of long-term potentiation and induces retrograde amnesia in rats. Brain Res 1075:60-67

81. De Oliveira AL, De Oliveira LF, Camboim C, Diehl F, Genro BP, Lanziotti VB, Quillfeldt JA (2005) Amnestic effect of intrahippocampal AM251, a CB1-selective blocker, in the inhibitory avoidance, but not in the open field habituation task, in rats. Neurobiol Learn Mem 83:119-124

82. Campolongo P, Roozendaal B, Trezza V, Hauer D, Schelling G, McGaugh JL, Cuomo V (2009) Endocannabinoids in the rat basolateral amygdala enhance memory consolidation and enable glucocorticoid modulation of memory. Proc Natl Acad Sci U S A 106:4888-4893

83. Ganon-Elazar E, Akirav I (2009) Cannabinoid receptor activation in the basolateral amygdala blocks the effects of stress on the conditioning and extinction of inhibitory avoidance. $\mathrm{J}$ Neurosci 29(36):11078-11088

84. Jamali-Raeufy N, Nasehi M, Zarrindast MR (2011) Influence of N-methyl D-aspartate receptor mechanism on WIN55,212-2-induced amnesia in rat dorsal hippocampus. Behav Pharmacol 22(7):645-654

85. Moshfegh A, Babaei P, Oryan S, Soltani B, Zarrindast MR (2011) Involvement of dorsal hippocampal alpha-1-adrenergic receptors in the effect of WIN55,212-2 on memory retrieval in inhibitory avoidance task. Neurosci Lett 489:69-73

86. Basavarajappa BS, Nagre NN, Xie S, Subbanna S (2014) Elevation of endogenous anandamide impairs LTP, learning, and memory through CB1 receptor signaling in mice. Hippocampus 24:808-818

87. Bucherelli C, Baldi E, Mariottini C, Passani MB, Blandina P (2006) Aversive memory reactivation engages in the amygdala only some neurotransmitters involved in consolidation. Learn Mem 13(4):426-430

88. Takahashi RN, Pamplona FA, Fernandes MS (2005) The cannabinoid antagonist SR141716A facilitates memory acquisition and consolidation in the mouse elevated T-maze. Neurosci Lett 380(3): 270-275

89. Wolff MC, Leander JD (2003) SR141716A, a cannabinoid CB1 receptor antagonist, improves memory in a delayed radial maze task. Eur J Pharmacol 477(3):213-217

90. Rinaldi-Carmona M, Barth F, Heaulme M, Alonso R, Shire D, Congy C, Soubrie P, Breliere JC et al (1995) Biochemical and pharmacological characterization of SR141716A, the first potent and selective brain cannabinoid receptor antagonist. Life Sci 56(23-24):1941-1947

91. Pertwee RG (2005) Inverse agonism and neutral antagonism at cannabinoid CB1 receptors. Life Sci 76:1307-1324

92. Robinson L, McKillop-Smith S, Ross NL, Pertwee RG, Hampson RE, Platt B, Riedel G (2008) Hippocampal endocannabinoids 
inhibit spatial learning and limit spatial memory in rats. Psychopharmacology 198(4):551-563

93. Lichtman AH (2000) SR141716A enhances spatial memory as assessed in a radial-arm maze task in rats. Eur J Pharmacol 404: 175-179

94. Marsicano G, Wotjak CT, Azad SC, Bisogno T, Rammes G, Cascio MG, Hermann H, Tang J et al (2002) The endogenous cannabinoid system controls extinction of aversive memories. Nature 418:530-534

95. Tan H, Lauzon NM, Bishop SF, Chi N, Bechard M, Laviolette SR (2011) Cannabinoid transmission in the basolateral amygdala modulates fear memory formation via functional inputs to the prelimbic cortex. J Neurosci 31(14):5300-5312

96. Roche M, O'Connor E, Diskin C, Finn DP (2007) The effects of $\mathrm{CB} 1$ receptors antagonism in the right basolateral amygdala on conditioned fear and associated analgesia in rats. Eur J Neurosci 26:2643-2653

97. Riedel G, Davies SN (2005) Cannabinoid function in learning, memory and plasticity. Handb Exp Pharmacol 168:445-477

98. Lin Q, Yang Q, Liu D, Sun Z, Dang H, Liang J, Wang YX, Chen J et al (2011) Hippocampal endocannabinoids play an important role in induction of long-term potentiation and regulation of contextual fear memory formation. Brain Res Bull 86:139-145

99. Wise LE, Iredale PA, Lichtman AH (2008) The cannabinoid CB1 receptor antagonist $\mathrm{CE}$ prolongs spatial memory duration in a rat delayed radial arm maze memory task. Eur J Pharmacol 590(1-3): 246-249

100. Bolognini D, Cascio MG, Parolaro D, Pertwee RG (2012) AM630 behaves as a protean ligand at the human cannabinoid CB2 receptor. Brit J Pharmacol 165(8):2561-2574

101. Häring M, Marsicano G, Lutz B, Monory K (2007) Identification of the cannabinoid receptor type 1 in serotonergic cells of raphe nuclei in mice. Neuroscience 146(3):1212-1219

102. Ross RA, Brockie HC, Stevenson LA, Murphy VL, Templeton F, Makriyannis A, Pertwee RG (1999) Agonist-inverse agonist characterization at CB1 and CB2 cannabinoid receptors of L759633, L759656 and AM630. Brit J Pharmacol 126(3):665-672

103. Hill MN, McEwen BS (2010a) Involvement of the endocannabinoid system in the neurobehavioural effects of stress and glucocorticoids. Prog Neuro-Psychopharmacol Biol Psychiatry 34:791-797

104. Marsicano G, Lafenêtre P (2009) Roles of the endocannabinoid system in learning and memory. Curr Top Behav Neurosci 1:201-230
105. Atsak P, Roozendaal B, Campolongo P (2012) Role of the endocannabinoid system in regulating glucocorticoid effects on memory for emotional experiences. Neuroscience 204:104-116

106. Degroot A, Nomikos GG (2004) Genetic deletion and pharmacological blockade of CB1 receptors modulates anxiety in the shockprobe burying test. Eur J Neurosci 20:1059-1064

107. Jacob W, Marsch R, Marsicano G, Lutz B, Wotjak CT (2012) Cannabinoid CB1 receptor deficiency increases contextual fear memory under highly aversive conditions and long-term potentiation in vivo. Neurobiol Learn Mem 98:47-55

108. Maccarrone M, Valverde O, Barbaccia ML, Castane A, Maldonado R, Ledent C, Parmentier M, Finazzi-Agrò A (2002) Age-related changes of anandamide metabolism in CB1 cannabinoid receptor knockout mice: correlation with behaviour. Eur $\mathrm{J}$ Neurosci 15:1178-1186

109. Reibaud M, Obinu MC, Ledent C, Parmentier M, Bohme GA, Imperato A (1999) Enhancement of memory in cannabinoid CB1 receptor knock-out mice. Eur J Pharmacol 379:R1-R2

110. Fanselow MS (2000) Contextual fear, gestalt memories and the hippocampus. Behav Brain Res 110(1-2):73-81

111. Sacchetti B, Lorenzini CA, Baldi E, Tassoni G, Bucherelli C (1999) Auditory thalamus, dorsal hippocampus, basolateral amygdala and perirhinal cortex role in the consolidation of conditioned freezing to context and to acoustic conditioned stimulus in the rat. J Neurosci 19(21):9570-9578

112. Li Y, Kim J (2016) CB2 cannabinoid receptor knockout in mice impairs contextual long-term memory and enhances spatial working memory. Neural Plast doi. doi:10.1155/2016/9817089

113. Varvel SA, Wise LE, Niyuhire F, Cravatt BF, Lichtman AH (2007) Inhibition of fatty-acid amide hydrolase accelerates acquisition and extinction rates in a spatial memory task. Neuropsychopharmacology 32:1032-1041

114. Hasanein P, Teimuri Far M (2015) Effects of URB597 as an inhibitor of fatty acid amide hydrolase on WIN55, 212-2-induced learning and memory deficits in rats. Pharmacol Biochem Behav 131:130-135

115. Varvel SA, Cravatt BF, Engram AE, Lichtman AH (2005) Fatty acid amide hydrolase (-/-) mice exhibit an increased sensitivity to the disruptive effects of anandamide or oleamide in a working memory water maze task. J Pharmacol Exp Ther 31:251-257

116. Panlilio LV, Justinova Z, Goldberg SR (2013) Inhibition of FAAH and activation of PPAR: new approaches to the treatment of cognitive dysfunction and drug addiction. Pharmacol Ther 138:84-102 